\title{
The Sesquiterpenes from Cacalia tangutica
}

\author{
Zhen Ling Liu, Qing Liu, ${ }^{\dagger}$ and Xuan Tian \\ College of Chemistry and Chemical Engineering, State Kev Laboratony of Applied Organic Chemistr, Lanzhou Chwersin, \\ Lanzhou 730000 , P.R. China. ${ }^{*}$-mail: xuantialzu.edu.ch \\ ${ }^{\dagger}$ Department of Chemical Engineering and Pharmacy, College of Material Science and Engineering. Huaqiao Universitw, \\ Quanzhou, Fuijan 362011. P.R. China \\ Received June 21, 2006
}

Key Words : Cacalia tangutica. Compositae. Sesquiterpenes

Cacalia tangutica belonged to the tribe Compositae have long been used as Chinese traditional folk herbs to treat headache. dizziness, hemiplegia. rheumatism. tussis and phlegm. ${ }^{1}$ Resently. our continuing studies on this plant revealed the presence of diversiform sesquiterpenes from a petrol extract of the aerial parts. "The seven sesquiterpenes isolated were three eremophilane sesquiterpenes $(\mathbf{1 - 3})^{3-5}$ including novel one (1). one known guaianetype sesquiterpeoid $(4){ }^{6}$ one alloromadendrane sesquiterpene $(5)^{7.8}$ and two eudesmane sesquiterpenes $(6.7)^{5-11}$ (Figure 1).

Compound 1. a pink gum, $[\alpha]_{D}^{21)}+10\left(c 1.30, \mathrm{CHCl}_{3}\right)$, has the molecular formula $\mathrm{C}_{1 \leq} \mathrm{H}_{2} \pm \mathrm{O}_{4}$ (HR-ESIMS: $m z 267.1597$ $[\mathrm{M}+1]^{+}$. calcd. for $\mathrm{C}_{1 \leqslant} \mathrm{H}_{33} \mathrm{O}_{4}$ 267.1591). Its IR and UV spectra showed the presence of a hydroxyl $\left(3323 \mathrm{~cm}^{-1}\right)$ and $\alpha, \beta$-unsaturated carbonyl systems - a ketone (1660, 1613 $\mathrm{cm}^{-1}$ and $\lambda_{\text {max }} 244 \mathrm{~mm}, 203 \mathrm{~mm}$ ). Analysis of the ${ }^{1} \mathrm{H}$ NMR and ${ }^{13} \mathrm{C}$ NMR (DEPT) spectnum of 1 along with HMQC experiment. the fifteen signals in ${ }^{13} \mathrm{C}$ NMR and the signals of four methyl groups ( $\delta_{\mathrm{H}}: 1.17 \mathrm{~s} . \delta_{\mathrm{C}}: 18.5: \delta_{\mathrm{H}}: 1.27 \mathrm{~d} . J=$ $\left.6.6 \mathrm{~Hz}, \delta_{\mathrm{C}}: 11.8: \delta_{\mathrm{H}}: 1.51 \mathrm{~s} . \delta_{\mathrm{C}}: 24.4: \delta_{\mathrm{H}}: 1.55 \mathrm{~s} . \delta_{\mathrm{C}}: 24.7\right)$ identified 1 as eremophlane sesquiterpene. The two olefinic signals $\left(\delta_{\mathrm{H}}: 6.06 \mathrm{~s} . \delta_{\mathrm{C}}: 125.3(\mathrm{CH}): \delta_{\mathrm{H}}: 7.21 \mathrm{~s} . \delta_{\mathrm{C}}: 150.9\right.$ (CH) combined with HMBC correlations $\left(\delta_{\mathrm{H}}: 6.06 \mathrm{~s} / \delta\right.$ :
$138.7(\mathrm{C}) .42 .9(\mathrm{C})$, and $30.2\left(\mathrm{CH}_{2}\right): \delta_{\mathrm{H}}: 7.21 \mathrm{~s} / \delta_{\mathrm{C}}: 47.3$ $(\mathrm{CH}) .42 .9(\mathrm{C}), 138.7(\mathrm{C}) .165 .7(\mathrm{C}), 185.7(\mathrm{C})$. and 83.4 (C)) indicated the presence of characteristics of an 8-oneeremophila-6,9-diene derivative. An additional hydroxy and a peroxyl groups were required for the molecular formula $\mathrm{C}_{15} \mathrm{H}_{22} \mathrm{O}_{4}$. The signals appeared at $\delta_{\mathrm{H}} 3.69$ (ddd. $1 \mathrm{H} . J=$ 11.4. 11.1. $4.2 \mathrm{~Hz}$ ) and $\delta_{\mathrm{C}} 71.1(\mathrm{CH})$ suggested the hydroxy group was equatorial stereochemistry at $\mathrm{C}-3$, $^{11}$ while the signals at $\delta_{\mathrm{H}} 1.51 \mathrm{~s} .1 .55 \mathrm{~s} .8 .78$ brs (H-peroxyl. $\mathrm{D}_{2} \mathrm{O}$ exchanged) and $\delta_{\mathrm{C}} 24.4\left(\mathrm{CH}_{2}\right), 24.7\left(\mathrm{CH}_{3}\right), 83.4(\mathrm{C})$ suggested the peroxyl group was at $\mathrm{C}-11 .{ }^{14}$ This was supported by the long range coupling of $\mathrm{C} .3(71.1, \mathrm{CH})$ with the methyl proton ( $1.27 \mathrm{~d} . J=6.6 \mathrm{~Hz}, \mathrm{H}-15)$ and the long range coupling of $\mathrm{C}-11 \mathrm{l}(83.4, \mathrm{C})$ with the methyl protons $(1.5 \mathrm{I} \mathrm{s}$. $\mathrm{H}-12$ : and $1.55 \mathrm{~s} . \mathrm{H}-13$ ) in the HMBC spectrum. In the ${ }^{1} \mathrm{H}-$ ${ }^{\mathrm{l}} \mathrm{H}$ COSY spectrum. $\mathrm{H}-4(\delta 1.42 \mathrm{~d} J=11.4 \mathrm{~Hz})$ and $\mathrm{H}-2(\delta$ $2.27 \mathrm{~m}$ ) were also correlated with $\mathrm{H}-3$.

To allow the assignments of structure 1 rigorously. a simple reductive reaction has been taken place as followed (see Figure 2). Compound $\mathbf{1}$ has been selectively reduced to compound 1-1 by potassium iodide in the solution of dilute acetic acid.

The produce 1-1. a pale yellow oil, has the molecular<smiles>C[C@@H]1[C@H](O)CCC2CC3C(=O)C(C(C)(C)O)=C[C@]3(C)[C@@]21C</smiles>

1

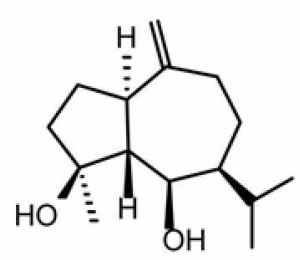

4<smiles>CC(C)=C1C[C@]2(C)C(=CC1=O)CC[C@H](O)[C@H]2C</smiles>

2<smiles>[CH]O[C@@H]1CCC2=CC(=O)C(=C(C)C)C[C@@]2(C)[C@H]1C</smiles>

3

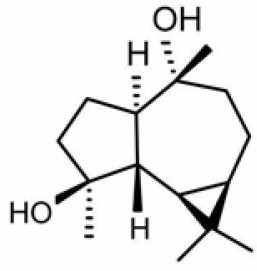

5
6<smiles>CC(C)C1=CC[C@]2(C)C(C1)[C@@](C)(O)CC[C@H]2O</smiles><smiles>C=C1CC[C@@H](O)[C@]2(C)CC[C@H](C(C)C)[C@H](O)[C@H]12</smiles>

7

Figure 1. The Sesquiterpenes from Cacalia tangutica. 


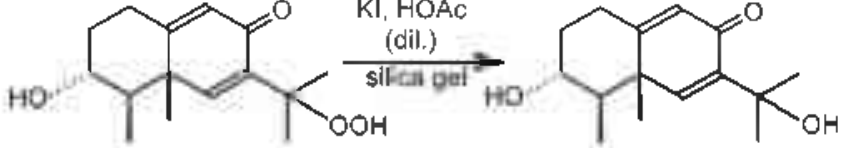

Compound $1,2 \mathrm{mg}$

Figure 2. The selectively reductive reaction of compound $\mathbf{1}$.

formula $\mathrm{C}_{15} \mathrm{H}_{22} \mathrm{O}_{3}$ (HR-ESIMS: $m z 273.1464[\mathrm{M}+\mathrm{Na}]^{-}$. caled. for $\mathrm{C}_{13} \mathrm{H}_{22} \mathrm{O}_{3} \mathrm{Na}$ 273.1461: EI-MS: $m z(\% \div 100)=$ $250[\mathrm{M}]^{+}(27) .235\left[\mathrm{M}^{-} \mathrm{CH}_{3}\right]^{-}(521) .217\left[235-\mathrm{H}_{2} \mathrm{O}\right]^{+}(778)$. $\left.199\left[217-\mathrm{H}_{2} \mathrm{O}\right]^{+}(411), 175(675), 43(10000)\right)$. In the ${ }^{1} \mathrm{H}$ NMR of 1-1. the olefinic signal (6.91 s. H-6) and the methyl signal $(1.47 \mathrm{~s}$. H-12) shifted to upfield compared with the olefinic signal (7.21 s. H-6) and the methyl signal (1.51 s. H12) of 1 at the same time the methyl signal $(1.56 \mathrm{~s} . \mathrm{H}-13)$ of 1-1 shifted to downfield compared with the methyl signal $(1.55 \mathrm{~s} . \mathrm{H}-13)$ of 1 . It was identical with petasitin. ${ }^{13,13}$ These indicate that compound 1 has been deoxidized to petasitin and it further demonstrated that a peroxyl group was in structure $1^{14}$

In the NOE spectrum of 1 , the NOEs [H-3 with $\mathrm{H}-\mathrm{I} 4$ $(3.3 \%)$ and $\mathrm{H}-15(1.8 \%)]$ were appeared. It was concluded that compound 1 was $3 \alpha$-hydroxy-11-peroxyl-eremophila-6. 9-dien-8-one.

Six known compounds 2-7 were the results after repeated column chromatography of the petrol extract of the aerial parts of Cacalia tangutica and were deduced by spectral data as two eremophilane sesquiterpenes: isopetasol (2) ${ }^{3,4}$ and isopetasin (3) ${ }^{3,-5}$ one guaianetype sesquiterpeoid: Teucladiol (4). ${ }^{6}$ one alloromadendrane sesquiterpene: armadendrane- $\beta \beta .10 \alpha$-diol $(5)^{7,8}$ and two endesmane sesquiterpenes: oplodiol $(6)^{9,10}$ and $1 \beta .6 \alpha$-dilydroxyedues $4(15)$-ene (7). ${ }^{11}$

Compound 1 was tested for in vitro antitumor activity against BEL-7402 (human liver carcinoma) and A-549 (human lung cancer) by the method of the cells stained with sulforhodamine $\mathrm{B}(\mathrm{SRB}){ }^{\text {15 }}$ Test plates were incubated for 3 days. The inlibiting activity with $\mathrm{IC}_{\text {și }}$ values $(23.9 \mu \mathrm{g} / \mathrm{mL}$. $21.8 \mu \mathrm{g} / \mathrm{mL}$ ) were determined as compared with Etoposide ${ }^{16}$ (IC si values: $7.00 \mu \mathrm{g} / \mathrm{mL}$. $7.14 \mu \mathrm{g} / \mathrm{mL}$ ). The result showed that compound 1 was able to inhibit the growth of BEL-7402 and $\mathrm{A}-549$ within measure.

\section{Experimental Section}

General Methods. IR spectra were measured on a Nicolet AVATAR 360 FT-IR instrument ( $\mathrm{KBr}$ pellet). UV spectra was measured on a Shimadzu UV-260 spectrometer. ID and 2D NMR spectrometer were measured on a Bruker AM400FT-NMR spectrometer and a Varian Mercury'-300BB NMR spectrometer with TMS as inemal standard. HRESIMS were recorded on a Bnuker APEX II. EI-MS on a HP $5988 \mathrm{~A} \mathrm{GC/MS}$ instrument. Optical rotations were measured using Perkin Elmer Model 341. Silica gel (200-300 mesh) was used for CC. silica $\mathrm{GF}_{\leq \leq 4}(10-40 \mu)$ for TLC were supplied by the Qingdao Marine Chenical factory. Qingdao.

P. R. China. Spots were detected on TLC under UV lamp or by heating after spraying with $5 \% \mathrm{H}_{2} \mathrm{SO}_{4}$ in $\mathrm{C}_{2} \mathrm{H}_{5} \mathrm{OH}$ ( $v / v)$.

Plant Material. The aerial parts of Cacalia tangutica. were collected in Minhe county. Qinhai province of China in October 1997, and identified by Prof. JiZhou Sun of Department of Biology. Lanzhou University: A voucher specimen (NO. 0108298) is deposited in Department of Biology: Lanzhou Univerisity:

Extraction and Isolation. Dried, powdered aerial parts (5750 g) of Cacalia tangutica were extracted with methanol by percolation at room temperature to give a residue $(796 \mathrm{~g})$ after evaporation. This residue was partitioned between petroleum ether $\left(60-90^{\circ}\right)$ and $\mathrm{H}_{2} \mathrm{O}$. The petroleum ether (60$\left.90^{\circ}\right)$-soluble portion $(118 \mathrm{~g}$ ) was separated on CC over 1000 $\mathrm{g}$ silica gel with a gradient of petroleum ether $\left(60-90^{\circ}\right)$ acetone $(40: 1: 20: 1: 18: 1: 15: 1: 12: 1: 10: 1: 7: 1: 5: 1$ : $3: 1: 1: 1$ and $0: 1)$ as eluent. Compound $1(8 \mathrm{mg})$ was isolated during elution with petroleum ether $\left(60-90^{\circ}\right)$ acetone $(10: 1)$ and afforded after prep. tlc of the eluates 5-7 with $\mathrm{C}_{6} \mathrm{H}_{6}-\mathrm{EtOAc}(15: 1)$.

Compounds 2. 4 and 7 were obtained from the fractions of petroleum ether $\left(60-90{ }^{\circ} \mathrm{C}\right)$ /acetone $(18: 1 ; 15: 1 ; 15 ; 1)$ and chromatographed on silica gel prep. plate using petroleum ether $\left(60-90^{\circ}\right)$-EtOAc $(15: 1)$.

The fractions of petroleum ether $\left(60-90^{\circ} \mathrm{C}\right) /$ acetone $(12$ : 1: $12: 1: 10: 1)$ was purified by a silica gel column and eluting with a gradient of petrol-EtOAc $(20: 1: 18: 1: 15: 1$. $12: 1: 10: 1: 7: 1: 5: 1: 3: 1: 1: 1$ and $0: 1$ ) to yield pure compounds 3.5 and 6 .

$3 \alpha$-Hydroxy-11-peroxyl-eremophila-6,9-dien-8-one (1): $\mathrm{C}_{15} \mathrm{H}_{22} \mathrm{O}_{4}$, a pink gum. $[\alpha]_{\mathrm{D}}^{301}:+10\left(c 1.30 . \mathrm{CHCl}_{3}\right)$; HRESIMS: $m z 267.1597[\mathrm{M}+1]^{+}$. calcd. for $\mathrm{C}_{15} \mathrm{H}_{23} \mathrm{O}_{4} 267.1591$; EI-MS: $m z(\% \div 100)=266[\mathrm{M}]^{-}(18), 248\left[\mathrm{M}-\mathrm{H}_{2} \mathrm{O}\right]^{+}(204)$,

Table 1. The NMR spectral data of compound $1\left(300 \mathrm{MHz}, \mathrm{CDCl}_{3}\right.$ TMS as intemal standard)

\begin{tabular}{lllr}
\hline No. & \multicolumn{1}{c}{$\delta_{\mathrm{H}}(\mathrm{ppm})$} & $\begin{array}{c}\delta(\mathrm{DEPT}) \\
(\mathrm{ppm})\end{array}$ & \multicolumn{1}{c}{$\mathrm{HMBC}^{\alpha}$} \\
\hline 1 & $2.00 \mathrm{~m}, 2.47 \mathrm{~m}$ & $30.2\left(\mathrm{CH}_{2}\right)$ & $\mathrm{C}-1 / \mathrm{H}-(2), 9$ \\
2 & $1.38 \mathrm{~m}, 2.27 \mathrm{~m}$ & $36.3\left(\mathrm{CH}_{2}\right)$ & $\mathrm{C}-2 / \mathrm{H}-(1)$ \\
3 & $3.69 \mathrm{ddd}$ & $71.1(\mathrm{CH})$ & $\mathrm{C}-3 / \mathrm{H}-15$ \\
& $(11.4,11.1,4.2 \mathrm{~Hz})$ & & \\
4 & $1.42 \mathrm{~m}$ & $47.3(\mathrm{CH})$ & $\mathrm{C}-1 / \mathrm{H}-6,14,(15)$ \\
5 & & $42.9(\mathrm{C})$ & $\mathrm{C}-5 / \mathrm{H}-1,(6), 9,(14), 15$ \\
6 & $7.21 \mathrm{~s}$ & $150.9(\mathrm{CH})$ & $\mathrm{C}-6 / \mathrm{H}-14$ \\
7 & & $138.7(\mathrm{C})$ & $\mathrm{C}-7 / \mathrm{H}-(6), 9,12,13$ \\
8 & & $185.7(\mathrm{C})$ & $\mathrm{C}-8 / \mathrm{H}-6$ \\
9 & $6.06 \mathrm{~s}$ & $125.3(\mathrm{CH})$ & $\mathrm{C}-9 / \mathrm{H}-1$ \\
10 & & $165.7(\mathrm{C})$ & $\mathrm{C}-10 / \mathrm{H}-(1), 6,14$ \\
11 & & $83.4(\mathrm{C})$ & $\mathrm{C}-11 / \mathrm{H}-6,(12),(13)$ \\
12 & $1.51 \mathrm{~s}$ & $24.4\left(\mathrm{CH}_{3}\right)$ & $\mathrm{C}-12 / \mathrm{H}-(13)$ \\
13 & $1.55 \mathrm{~s}$ & $24.7(\mathrm{CH})$ & $\mathrm{C}-13 / \mathrm{H}-(12)$ \\
14 & $1.17 \mathrm{~s}$ & $18.5\left(\mathrm{CH}_{3}\right)$ & $\mathrm{C}-14 / \mathrm{H}-4,6$ \\
15 & $1.27 \mathrm{~d}(6.6 \mathrm{~Hz})$ & $11.8\left(\mathrm{CH}_{3}\right)$ & $\mathrm{C}-15 / \mathrm{H}-(4)$ \\
\hline
\end{tabular}

"Two-bond correlations are indicated in parentheses. 
235 (1172). 233 (615). 230 (815), 43 (10000): UV (MeOH): $\lambda_{\max }=203.244 \mathrm{~nm} ; \mathrm{IR}(\mathrm{KBr}): v_{\text {max }}=1029,1265.1374$. 1451, 1613, 1660, 2867, 2928, 2978. $3323 \mathrm{~cm}^{-1} ;{ }^{1} \mathrm{H}$ and ${ }^{13} \mathrm{CNMR}\left(\mathrm{CDCl}_{3}, 300 \mathrm{MHz}\right)$ see Table $\mathrm{I}$.

Petasitin (1-1): $\mathrm{C}_{15} \mathrm{H}_{22} \mathrm{O}_{3}$. pale yellow oil. HR-ESIMS: $m z$ $273.1464\left[\mathrm{M}+\mathrm{Na}^{-}\right.$, calcd. for $\mathrm{C}_{15} \mathrm{H}_{22} \mathrm{O}_{3} \mathrm{Na}$ 273.1461: EIMS: $m z(\% \div 100)=250[\mathrm{M}]^{-}(27), 235\left[\mathrm{M}-\mathrm{CH}_{3}\right]^{+}(52 \mathrm{l})$. $217\left[235-\mathrm{H}_{2} \mathrm{O}\right]^{+}(778), 199\left[217-\mathrm{H}_{2} \mathrm{O}\right]^{+}(4 \mathrm{ll}), 175(675), 43$ (10000): ${ }^{1} \mathrm{H} \mathrm{NMR}\left(\mathrm{CDCl}_{3}, \mathrm{TMS}\right): \delta 3.69 \mathrm{~m}(\mathrm{H}-3), 6.91 \mathrm{~s}(\mathrm{H}-$ 6). $6.10 \mathrm{~s}(\mathrm{H}-9) .1 .47 \mathrm{~s}(\mathrm{H}-12) .1 .56 \mathrm{~s}(\mathrm{H}-13) .1 .16 \mathrm{~s}(\mathrm{H}-14)$. $1.25 \mathrm{~d}(J=6.0 \mathrm{~Hz} . \mathrm{H}-15)$.

Antitumor Testing. In vitro antitumor activities against BEL-7402 (human liver carcinoma) and A-549 (human lung cancer) of compound 1 by the method of the cells stained with sulforhodamine $\mathrm{B}$ (SRB) carried out according to: ${ }^{15}$ Test plates were incubated for 3 days at $37^{\circ} \mathrm{C}$ in a $5 \% \mathrm{CO}_{2}$ incubator. After the incubation periods, cells were fixed by the addition of aqueous TCA solution $\left(4^{\circ} \mathrm{C}\right.$ for $\left.30 \mathrm{~min}\right)$ and the fixed cells were stained with SRB $(0.4 \% \mathrm{w} / \mathrm{v}$ in $1 \%$ aqueous acetic acid) for $30 \mathrm{~min}$. the bound dye was solubilized with $200 \mu \mathrm{L}$ of $10 \mathrm{mM}$ tris-base (pH 10.0 ), and absorbance was determined at $515 \mathrm{~nm}$ in Vis region.

\section{References}

1. Jiangsu new medical college. Zhong yoo da ci dian the glossary of medicinal herbs, in Chmese) 1977.549.

2. Liu. Z. L.: Tian. X. Bull. Korew Chent Soc. 2004. 25. 1078.

3. Sugama. K.: Hayashi. K.: Nakagawa. T.: Mitsuhashi. H.: Yoshida. N. Phutochemisto 1983, 22, 1619 .

4. Bohlmann. F.: Zdero. C. Phytochenistry 1978. 17, 1337.

5. Zhao. Y.: Peng. H. R.: Jia. Z. J. Jounal of Natwal Products 1994. 57. 1626 .

6. Brun1o. M.: Torre. M. C. D.: Rodríguez. B.: Omar. A. A. Phtochentistry 1993. 34. 245.

7. Beechan. C. M.: Djerass. C. Tetrahedron 1978. 34, 2503.

8. Goldsby, G. Burke. B. A. Phyochemisty 1987. 26, 1059

9. Herz. W: Watanabe. K. Plytochemistry 1983, 22.1457.

10. Feligiano. A. S.: Medarde. M.: Gordaliza. M.: Olmo. E. D.: Miguel del Corral. J. M. Phytochemistry 1989. 28. 2717.

11. Ohmoto. T.: Theda. K.: Nomura. S.: Shimizu. M.: Saito. S. Chent. Pham. Bull. 1987, 35. 2272.

12. Naya. K.: Takagi. I. Tetrahedron Letters 1968.9,629.

13. Takagi. I.: Tazuke. Y; Nava, K. Bull. Chom Soc. Japom 1977,50. 3320.

14. Duper. S.: Gernz. T.: Jahupovic. T.: Bohlmantn. F.: Niemeyer. H. M. Phtochemistry 1991. 30. 1211 .

15. Lee. S. K.: Nam. K. A.: Heo. Y. H. Plonta. Hed 2003. 69. 21.

16. Canel. C; Moraes. R. M.; Dayan, F. E; Ferreira, D. Plntochemisty 2000. 5t. 115 